\title{
Spending Money on Hiring Others to Attend Classes Instead of Themselves: An Emerging Trend of Chinese College Students to Truant from Class?
}

\author{
Chengmeng Zhang ${ }^{1}$, Rui $\mathrm{Li}^{2 *}$ and Yuxin Pang ${ }^{2 *}$ \\ ${ }^{1}$.College of Management, Shenzhen University; a582019033@ hotmail.com \\ ${ }^{2}$.College of Law, Chengdu University of Technology; 844912392@qq.com \\ *Correspondence 1:844912392@qq.com; \\ Correspondence 2: 3106509176@qq.com;
}

\section{ABSTRACT}

Nowadays, in the Chinese colleges, there are many ways for the students to truant from classes and not be caught by the teachers. Spending money on hiring other students to attend classes instead of themselves is becoming a mainstream form and as a widely known secrets among Chines college students. This paper analyzed the status quo of the students hired others to attend classes from three perspectives: college management, teachers teaching methods and the value of college students. The data shows that in the schools, the formalities cumbersome process of asking for leave, the loose discipline, and the laxity of classroom attendance passed the test of significance, which played an important role in the prevalence of hiring other students to attend classes. Relations with university counselor, and the boring content of the course also has a significant impact on the class. As the college students, the lack of correct values and integrity affected their behavior, causing the phenomenon of hiring others to attend classes.

\section{Keywords: truant; higher education; college students}

\section{Introduction}

The phenomenon of college students spending money on hiring others to attend classes instead of themselves has always been a hard problem for college managers and teachers. In order to solve this problem, college managers and teachers have also developed various classroom check-in systems, which made many students have a tangled mentality: attend class or not? How to truant class and escape the punishment by the teachers? Therefore, the emerging trend that "hiring others to attend classes", is becoming more and more popular among a lot of college students. Of course, as a hot business, hiring others to attend classes is charged. Because of various reasons, the students had to truant class and can't attend class themselves. In order to avoid the serious consequences such as course failed, through QQ(one of the hottest instant message software in China, can realize social function through chat groups), Baidu Post-Bar(a web forum dedicated to social on specific topics in China) and other sources to find other students who was idle, paid them money and let them attend the designated classes.

The usual view is that truants are lost in society and get in troubled. But mankind is a rational animal. People often act after weighing the pros and cons of behavior and choosing the most attractive things. This kind of "rationality" is also reflected in the phenomenon of spending money on hiring people to attend classes. In a sense, the students rather do a part-time job which can gain work experience and find a better job in the future. There are also other ways more meaningful than the boring classes, participating in student association activities which can make friends and enhance social capital; playing computer games can relax and gain pleasure and so on. Therefore, after rationally weighing the pros and cons, college students choose to truant to do these "more meaningful things", but they are also afraid that the attendance rate would affect the test scores, causing serious consequences such as course failed. The strong demand brings market chances, some students have chosen to do a part-time job, take part in student association activities and play computer games, some students prefer to exchange their free time to substitute others to attend classes for money, then the deal was appeared and completed. However, this behavior which seemingly rational actually reducing their career development opportunities in the future, because they have not mastered useful knowledge and skills. 
Spending money on hiring others to attend classes instead of themselves is a non-traditional phenomenon of truancy. There are many well-known sociological, psychological and environmental factors promote truancy. The past studies have focused on the causes and effects of truancy. Whether or not truancy is related to students' willingness to learn and their economic situation, as well as school environment and community [1,2,3]. The students choose to be absent from classes through truancy, they risk losing the opportunity for acquiring foundational knowledge, social and economic skills [4]. Shute (2015) elucidated there is something wrong with the education or courses system when truancy occurs [5], some students went to campus but absent from classes [6]. Janosz (2008) highlighted that student, family, and peer characteristics influenced education participation, included truancy phenomenon [7]. Some scholars hold similar views that as a rational decision, the students who won't tolerate academic subjects that seem inadequate and teachers who seem poorly prepared, chosen to play truant finally $[8,9]$.

Most past studies focus on truancy among teenagers, especially the students from high school and junior high school. Wang (2013) found that lower behavioral and emotional engagement and greater problem behaviors were associated with truanting school [10,11]. By increasing student behavioral participation in classroom and school-based activities, can increase the emotional connection with schools, it will reduce bad behavior such as truant. [12]. There are still many scholars who treat truancy phenomenon as problem behavior, but not linked to the social environment [13]. Hemphill (2010) elucidated that truancy is related to family income level [14], but some scholars elucidated that truancy is not caused by the economy, but by interaction with the community environment years ago [15]. If truancy is regarded as a student's personal choice based on environment, then truancy or not is related to whether the environment meets the individual's needs. If the educational environment does not meet the needs, it may cause the students to make the decision of truancy [16]. Self-determination theory also showed that students rely on personal judgment and perception of the environment when making decisions about truancy or not [17]. In addition to family environment, students spend most of their time on campus, so school environment will have an impact on students' behavior, that is, student's behavior will cause collective imitation or boycott among students. As a rebellion against traditional rules, the truancy behavior will be imitated by most students if without punishment [18]. The teacher-student relationship is also an important factor, which will directly affect students' interest in learning and may lead to truancy. Some quantitative research proved this point that students' evaluation of teachers affects students' expected accomplishments [19]. Rooodar (2011) had used meta-analysis to study the emotional relationship between teachers' and students', and how it influences students' school participation and achievement [20]. There is no doubt that truancy is not appropriate behavior, whether it is the personal will or environmental impact. Henry (2010) pointed out that truancy would lead to less contact with schools and substance abuse [21]. Vaughn (2013) had shown that truancy and dropping out of school will make teenagers more likely to commit crimes by the data [22].

In sum, Past studies had studied the influencing factors of teenagers' truancy, and analyzed the possible harm of truancy, but few studies referred to college students' truancy, especially the behavior of spending money on hiring others to attend classes. This study focuses on the reasons why students prefer to spend money on hiring others to truancy than attending class themselves. It analyses the reasons from three perspectives which include school management, teacher-student relationship, and students' personal willings and argued the way how to solve this unhealthy phenomenon.

\section{Materials and Methods}

This study adopts a quantitative approach. Quantitative research uses intuitive data to present the social outlook concisely and gives analysis and prediction based on scientific and reasonable statistical methods. Quantitative research can't be distinguished from the case study method which belongs to empirical research. The accuracy of data analysis and interpretation is usually related to the ability of researchers to apply knowledge in a broad context of action (Giddens, 1984) [23].

This paper chooses whether college students have the action of hiring others to attend classes as the dependent variable. The independent variables mainly refer to the three aspects that affect college students' choice of hiring people to attend classes, including schools, teachers and college students themselves. The school is the second home of Chinese college students. The school management model is inseparable from the possibility of college students 
choosing to hire others to attend classes. Each teacher has his own different teaching methods, but it does not necessarily apply to all students. Teacher-Student relations are also one of the important factors. College students are influenced by individualism, and they are preferred to enjoy pleasure themselves than attend class together, which had become a key aspect of the prevalence of hiring others to attend classes.

In order to study the phenomenon of college students' truant from classes, according to the quota sampling and stratified sampling method, the subject group selected 10 colleges and universities in the three provinces of Southwest China, covering "211 and 985 project "key universities, moderate universities, and junior colleges. The Chinese government divides universities into different levels, which enjoy different financial support from the government. Traditionally, students in key universities (such as 985 and 211 project key universities) have better entrance scores, stricter school management, and are generally considered to have better comprehensive quality.

This investigation is based on the paper questionnaire. The researcher gave a detailed explanation of the purpose of the research and what the participants were expected to do in the instructions of the survey. The participants were also told that their responses were confidential and only used for the research purpose. At the different levels of universities, a total of 640 questionnaires were distributed, of which 534 were valid and the effective rate was about $83.4 \%$. After data recovery, correlation analysis and logistic regression analysis were carried out with SPSS software.

\section{Results}

\section{1. the management of universities}

As can be seen from Table 1, the three variables have a significant impact on spending money on hiring others to attend classes instead of themselves, which included the formalities of ask for leave are cumbersome, the disciplinary action is weak, the loosen classroom attendance check-in and the lax supervision. The probability, the pvalues of the three variables are all $<0.05$, indicating that there is a $95 \%$ probability of negating the hypothesis, that is, the three variables with a significant correlation with "whether if have the idea of hiring people to attend classes".

Table 1. Interaction table between school and hiring others to attend classes

\begin{tabular}{|c|c|c|c|c|c|}
\hline \multirow{2}{*}{ problem } & \multirow{2}{*}{ Option } & \multicolumn{2}{|c|}{$\begin{array}{l}\text { whether if have the idea of hiring others to } \\
\text { attend classes. }\end{array}$} & \multirow{2}{*}{ Chi-square value } & \multirow{2}{*}{ Sig } \\
\hline & & Yes & no & & \\
\hline \multirow{2}{*}{$\begin{array}{l}\text { formalities of ask for leave } \\
\text { are cumbersome }\end{array}$} & Yes & $47.1 \%$ & $52.9 \%$ & \multirow{2}{*}{13.475} & \multirow{2}{*}{0.000} \\
\hline & no & $31.0 \%$ & $69.0 \%$ & & \\
\hline \multirow{2}{*}{ disciplinary action is weak } & Yes & $33.3 \%$ & $66.7 \%$ & \multirow{2}{*}{9.920} & \multirow{2}{*}{0.002} \\
\hline & no & $46.9 \%$ & $53.1 \%$ & & \\
\hline \multirow{2}{*}{$\begin{array}{c}\text { loosen class attendance } \\
\text { check in and lax supervision }\end{array}$} & Yes & $36.6 \%$ & $63.4 \%$ & \multirow{2}{*}{5.080} & \multirow{2}{*}{0.024} \\
\hline & no & $46.3 \%$ & $53.7 \%$ & & \\
\hline
\end{tabular}

From the interactive table, it can be found that under the circumstance that the formalities of ask for leave are cumbersome, the college students are more inclined to choose to hire others to attend classes instead ask for leave and it's a low-cost behavior. Under the emergency situation when unable to attend classes for themselves, the leave procedures are numerous and take a long time, the college students usually tend to choose to spend a little money on hiring others to attend classes simply and conveniently.

\section{2. the teaching methods of teachers}

From the perspective of teachers' teaching methods, there are two main variables that affect students' paid truancy behavior, "dislike of the teacher of that course" and "the boring course content" has a significant impact on hiring others to attend classes.

If teachers themselves do not have a high sense of responsibility for teaching and teaching methods cannot attract students' interest in learning, 64.3 percent of the students will tend to do other things to replace to attend class; 
the useless or meaningless courses will also increase students' truancy behavior, 60.5 percent of the students give up to attend class themselves because of the full course content.

\section{3. the value of college students}

Table 2. Interaction table of college students' own values and hiring others to attend class

\begin{tabular}{|c|c|c|c|c|c|}
\hline \multirow{2}{*}{$\begin{array}{c}\text { Problems with college } \\
\text { students }\end{array}$} & \multirow{2}{*}{ Option } & \multicolumn{2}{|c|}{ whether if hiring others to attend classes. } & \multirow{2}{*}{ Chi-square value } & \multirow{2}{*}{ Sig } \\
\hline & & Yes & no & & \\
\hline \multirow{2}{*}{$\begin{array}{c}\text { Lack of correct values and } \\
\text { integrity }\end{array}$} & Yes & $47.5 \%$ & $52.5 \%$ & \multirow{2}{*}{6.294} & \multirow{2}{*}{0.012} \\
\hline & no & $36.6 \%$ & $63.4 \%$ & & \\
\hline \multirow[b]{2}{*}{ Confused about the future } & Yes & $42.9 \%$ & $57.1 \%$ & \multirow[b]{2}{*}{0.384} & \multirow[b]{2}{*}{0.535} \\
\hline & no & $40.1 \%$ & $59.9 \%$ & & \\
\hline
\end{tabular}

As can be seen from Table 2, the lack of correct values and integrity awareness has a conspicuous impact on the idea of hiring others to attend classes through significant testing. After been experienced college entrance examinations, college students have great freedom and choice to enjoy college life. Whether confused about the future or not is not directly related to the idea of hiring others to attend classes. Truancy behavior is related to an individual's idea and judgment.

\section{4. the logistic regression analysis}

When the dependent variable is a categorical variable, logistic regression analysis is usually used to study the relationship between the categorical dependent variable and a set of explanatory variables. In this paper, "whether have the idea of hiring people to attend classes instead of yourself" as the dependent variable of the model, there are two possibilities for its value, yes and no. This article explores the factors of hiring people to attend classes in seven aspects: the formalities of asking for leave, disciplinary action, classroom attendance, teacher personal charm, course content, students' own values and integrity awareness, students' own goals, and requirements. These seven elements are models Independent variable. The logistic regression model constructed in this paper is as follows:

$$
\operatorname{logit}(p)=\beta 0+\beta 1^{*} X 1+\beta 2^{*} X 2+\beta 3^{*} X 3+\beta 4^{*} X 4+\beta 5^{*} X 5+\beta 6^{*} X 6+\beta 7^{*} X 7
$$

Where $\beta 0$ is a constant term, $\beta 1 \ldots \beta 7$ is a regression coefficient, $X 1=$ the formalities of ask for leave, $\mathrm{X} 2=$ discipline, $\mathrm{X} 3=$ class attendance, $\mathrm{X} 4=$ teacher personal charm, $\mathrm{X} 5=$ course content, $\mathrm{X} 6=$ student's own values and integrity awareness, X7 = students' own goals and requirements. The model is tested using the default stepwise regression method in SPSS software to select the independent variable. The significance test of the variables has been shown in Table 3. The significance level of each variable and the corresponding statistic value are shown in following table. Under the condition of a given significance level of 0.05 , the variables passing the significance test include the formalities of ask for leave, also the disciplinary action, and course content.

Table 3. Variable table in the logistic regression equation

\begin{tabular}{|c|c|c|c|c|c|c|}
\hline \multirow[b]{2}{*}{ variable } & \multicolumn{2}{|c|}{ Non-standardized coefficient } & \multirow[b]{2}{*}{$\operatorname{Exp}(B)$} & \multirow[b]{2}{*}{ df } & \multirow[b]{2}{*}{$\mathrm{t}$} & \multirow[b]{2}{*}{ Sig. } \\
\hline & $\mathrm{B}$ & Standard error & & & & \\
\hline (constant) & 1.265 & 0.084 & & 1 & 15.046 & 0.000 \\
\hline $\mathrm{X} 1$ & -0.161 & 0.042 & 0.851 & 1 & -3.799 & 0.000 \\
\hline $\mathrm{X} 2$ & 0.104 & 0.047 & 1.101 & 1 & 2.194 & 0.029 \\
\hline $\mathrm{X} 3$ & 0.027 & 0.048 & 1.027 & 1 & 0.570 & 0.569 \\
\hline $\mathrm{X} 4$ & 0.020 & 0.030 & 1.020 & 1 & 0.664 & 0.507 \\
\hline $\mathrm{X} 5$ & 0.067 & 0.029 & 1.069 & 1 & 2.301 & 0.022 \\
\hline X6 & 0.055 & 0.044 & 1.057 & 1 & 1.257 & 0.209 \\
\hline $\mathrm{X} 7$ & -0.08 & 0.046 & 0.923 & 1 & -0.174 & 0.862 \\
\hline
\end{tabular}


According to the above analysis, so the final model established is:

$$
\operatorname{logit}(\mathrm{p})=1.265-0.161 \mathrm{X} 1+0.104 \mathrm{X} 2+0.067 \mathrm{X} 5
$$

According to this formula, when other variables would be controlled, the formalities of ask for leave, also the disciplinary action, and course content have a significant impact on hiring others to attend classes.

\section{Discussion}

Hiring people to attend classes seriously affect the normal teaching order and learning atmosphere, resulting in extremely bad effects. Only from the institutional aspects, analyze the seriousness and harm of hiring people to attend classes, strengthen the study style and class style, serious school rules and regulations, to curb the continued spread of hiring people to attend classes. In addition, most of the classes only require someone to respond when they name, but the name and person are not considered one by one, so the relaxation of classroom attendance also provides favorable conditions for hiring people to attend classes. Don't like the class teacher mainly means don't like the teacher's teaching methods. Most college courses are not so exciting that the students can't afford to skip classes. Some teachers are perfunctory in class and they have no new ideas to read ppt, so that students feel that it is just another place to look at ppt. It is not worth wasting time. In addition, some of the curriculum is not reasonable, some of the content is boring and even inconsistent with the facts. Only to make up enough credits, which has damped the enthusiasm of college students. In this way, some students think that the class is dispensable but choose hiring people to attend classes under the oppression of absenteeism.

Without the constraints of parents and teachers, more choices are determined by themselves. Some college students have weak power in self-control, and they do not know how to enjoy the opportunities of learning. Some regarded study as a kind of suffering thing to freedom life. They hoping to avoid that suffering, truant from classes and sleeping or playing computer games to get more relaxed, which creates a commercial demand for hiring others to attend classes.

It is cumbersome to take the table or ask for leave to the teacher who is teaching the class it means you should fill the table in advance, then make the counselor signed it. Some students are unwilling to go through the troublesome formalities; therefore, they are more inclined to choose hiring others to attend classes. Under some emergencies (such as part-time job arrangement, societies, the appointment with boyfriend or girlfriend), students are unable to attend classes, there is also no time to complete complicated and time-consuming leave procedures, hiring someone to attend classes will be a more convenient choice. Disciplinary action has a prominent impact on hiring others to attend classes. With an objectively speaking, if a college student is punished by the universities during school time, it will form a deterrent to college students. But this deterrence does not work for some students. They often have a disregard for punishment. They are not afraid of violations and not afraid of being punished. Therefore, there has been a phenomenon of disregarding disciplinary action and choosing to hire others to attend classes. The content of the course has a remarkable impact on hiring others to attend classes. The past studies pointed out that the content of the course is boring, some of the courses are useless and meaningless. That courses are not based on the initiative and interest of students, which has damped the enthusiasm of college students for class. They think that class is dispensable but choose hiring others to attend classes, because of the punished by absent from classes.

\section{Conclusions}

The three factors of the formalities of ask for leave, disciplinary action, and course content have a significant impact on the mechanism of hiring others to attend classes. It is indicated that under the circumstance that the formalities of ask for leave are cumbersome and the weak disciplinary action, the college students are more inclined to choose hiring others to attend classes instead of themselves. It is also found in terms of the factors of the school management system, due to the education management system and the imperfect evaluation of classroom teaching quality, the phenomenon of hiring others to attend classes is rampant among Chinese college students. At the same time, the sig $=0.012<0.05$ (Table 3 ) in the interaction table indicates that the lack of correct values and integrity awareness has a noteworthy impact on the idea of hiring people to attend classes through the significance test, 
We all believe that the occurrence of hiring others to attend classes is related to the college students themselves. The lack of goals of life, moral cultivation and discipline knowledge, will lead to the phenomenon.

This research is based on the basis of past studies, to understand the current situation of hiring others to attend class instead of themselves, which is a new trend of truant. The analysis of the reasons for hiring others to attend classes from the three perspectives. From the perspective of school management, the low cost of violations and the weak internal constraints are crucial factors. As far as the teachers' teaching methods, the evaluation of course teaching quality is not perfect and the teachers' vocational skills are not strong would lead students to hire others to attend class. Thinking from the students, the students' core values are weakened and collapsed.

One limitation of our research is related to other subjective perspectives, and our data does not cover family factors, social factors, and others. For example, the family's improper guidance and excessive love of children in the process of establishing children's values lead to a lack of sense of integrity and responsibility. Another limitation is the size of the sample. There are not many students who have paid for hiring others to attend class instead of themselves, which reduces the power and credibility of the analysis.

Funding: This research was funded by the National College Students' Innovation and Entrepreneurship Training Program "The Mechanism and Guidance of College Students' Compensation for Classes", grant number 201710616077".

\section{References}

Bell A. J., Rosen L. A., Dynlacht D., (1994). Truancy intervention. The Journal of Research and Development in Education, 27, 203-211.

Lawson M. A., Lawson H. A., (2013). New conceptual frameworks for student engagement research, policy, and practice. Review of Educational Research, 83, 432-479.

Rodriguez L. F., Conchas G. Q., (2009). Preventing truancy and dropout among urban middle school youth: Understanding community-based action from the student's perspective. Education and Urban Society, 41(2), 216-247.

Coordinator, J. L. R., (2014). Factors associated with truancy. Journal of Counseling \& Development, 34(7), 431-436.

Shute, J. W., \& Cooper, B. S. (2015). Understanding in-school truancy. Phi Delta Kappan, 96(6), 65-68.

Shute, J., \& Cooper, B. S. (2014). Fixing truancy now: Inviting students back to class. Rowman \& Littlefield.

Janosz, M., Archambault, I., Morizot, J., \& Pagani, L. S. (2008). School engagement trajectories and their differential predictive relations to dropout. Journal of social Issues, 64(1), 21-40.

Chesney-Lind, Meda \& Nakano, Joanne. (2004). Arrest Trends, Gang Involvement, and Truancy in Hawaii: An Interim Report to the Twenty-Second Hawaii State Legislature. Honolulu, HI: University of Hawaii at Manoa.

Conolly M., O'Keeffe D. (2009). Don't fence me in: Essays on the rational truant (pp. 115-138). Buckingham, England: University of Buckingham Press.

Finn, J. D. (1989). Withdrawing from school. Review of Educational Research, 59, 117-142. doi: $10.2307 / 1170412$

Wang, M. T., \& Peck, S. (2013). Adolescent educational success and mental health vary across school engagement profiles. Developmental Psychology. Advance online publication. doi:10.1037/a0030028

Wang M.-T., Fredricks J. A., (2013). The reciprocal links between school engagement, youth problem behaviors, and school dropout during adolescence. Child Development, 85, 1-16. doi:10.1111/cdev.12138 
Wang, M. T., Dishion, T. J., Stormshak, E. A., \& Willett, J. B. (2011). Trajectories of family management practices and early adolescence behavioral outcomes in middle school. Developmental Psychology, 47, 13241341. doi:10.1037/a0024026

Hemphill S. A., Toumbourou, J. W., Smith R., Kendall G. E., Rowland B., Freiberg K., Williams J. W., (2010). Are rates of school suspension higher in socially disadvantaged neighborhoods? An Australian study. Health Promotion Journal of Australia, 21, 12-18. doi:10.1071/HE10012

Battin-Pearson S., Newcomb M. D., Abbott R. D., Hill K. G., Catalano R. F., Hawkins J. D., (2000). Predictors of early high school dropout: A test of five theories. Journal of Educational Psychology, 92, 568. doi:10.1037/0022-0663.92.3.568

Southwell N., (2006). Truants on truancy: A badness or a valuable indicator of unmet special educational needs? British Journal of Special Education, 33, 91-97.

Deci E. L., (2009). Large-scale school reform as viewed from the self-determination theory perspective. Theory and Research in Education, 7, 244-252. doi:10.1177/1477878509104329

Thapa A., Cohen J., Guffey S., Higgins-D’Alessandro A., (2013). A review of school climate research. Review of Educational Research, 83, 357-385. doi:10.3102/0034654313483907.

Chase P. A., Hilliard L., Geldhof G. J., Warren D., Lerner R., (2014). Academic achievement in the high school years: The changing role of school engagement. Journal of Youth and Adolescence, 43, 884-896.doi: 10.1007/s10964-013-0085-4

Roorda, D. L., Koomen, H. M. Y., Spilt J. L., Oort F. J., (2011). The influence of affective teacher-student relationships on students' school engagement and achievement: A meta-analytic approach. Review of Educational Research, 81, 493-529. doi:10.3102/0034654311421793.

Henry K. L., Thornberry T. P., (2010). Truancy and escalation of substance use during adolescence. Journal of Studies on Alcohol and Drugs, 71, 115-124.

Vaughn, M. G., Maynard, B. R. , Salas-Wright, C. P. , Perron, B. E. , \& Abdon, A. . (2013). Prevalence and correlates of truancy in the us: results from a national sample. Journal of Adolescence, 36(4), 767-776.

Giddens, A. (1984). Pp: 328-329. The constitution of society: Outline of the theory of structuration. Cambridge, UK: Polity Press. 